\title{
Plant-insect interactions: an evolutionary arms race between two distinct defense mechanisms
}

\author{
Marcia O. Mello and Marcio C. Silva-Filho*
}

Departamento de Genética, Escola Superior de Agricultura Luiz de Queiroz, Universidade de São Paulo, Av. Pádua Dias, 11, CP 83, 13.400-970 Piracicaba, SP, Brazil; *Corresponding author: mdcsilva@esalq.usp.br

Received: 22/04/2002, Accepted: 05/07/2002

In this review, plant-insect interaction is discussed as a dynamic system, subjected to continual variation and change. Plants developed different mechanisms to reduce insect attack, including specific responses that activate different metabolic pathways which considerably alter their chemical and physical aspects. On the other hand, insects developed several strategies to overcome plant defense barriers, allowing them to feed, grow and reproduce on their host plants. This review foccuses on several aspects of this complex interaction between plants and insects, including chemical-derived substances, protein-derived molecules and volatile compounds of plants whereas metabolization, sequestration or avoidance are in turn employed by the insects.

Key words: adaptation, co-evolution, herbivory.

Interação planta-inseto: uma disputa evolutiva entre dois mecanismos de defesa distintos: Nesta revisão, a interação planta-inseto é abordada como um sistema dinâmico, sujeito a contínuas variações e mudanças. As plantas desenvolveram diferentes mecanismos para reduzir o ataque de insetos, incluindo respostas específicas que ativam diferentes vias metabólicas as quais alteram consideravelmente suas características químicas e físicas. Por outro lado, os insetos desenvolveram várias estratégias para superar as barreiras defensivas das plantas, permitindo a sua alimentação, desenvolvimento e reprodução em seus hospedeiros. Esta revisão enfoca vários aspectos desta complexa interação entre plantas e insetos, incluindo substâncias derivadas de compostos químicos, moléculas produzidas a partir do processamento de proteínas e compostos voláteis das plantas, enquanto que a metabolização, seqüestro ou fuga são empregados em contrapartida pelos insetos.

Palavras-chave: adaptação, co-evolução, herbivoria.

\section{INTRODUCTION}

The evolution of plants transformed the terrestrial environment into a highly valuable resource for the herbivore community. In natural ecosystems, plants and insects are just some of the living organisms that are continuously interacting in a complex way. These two organisms are intimately associated since insects have several beneficial activities including defense and pollination while plants provide shelter, oviposition sites and food, the three main factors requested for insect proliferation (Panda and Khush, 1995). On the other hand, depending on the intensity of insect attack, herbivores might be extremely harmful to plants leading them to death.
Plant-insect interaction is a dynamic system, subjected to continual variation and change. In order to reduce insect attack, plants developed different defense mechanisms including chemical and physical barriers such as the induction of defensive proteins (Haruta et al., 2001), volatiles that attract predators of the insect herbivores (Birkett et al., 2000), secondary metabolites (Baldwin, 2001 and references herein; Kliebenstein et al., 2001) and trichome density (Fordyce and Agrawal, 2001) (figure 1). In parallel, insects developed strategies to overcome plant barriers such as detoxification of toxic compounds (Scott and Wen, 2001), avoidance mechanisms (Zangerl, 1990), sequestration of poison (Nishida, 2002 and references herein) and alteration of gene expression pattern (Silva et al., 2001) (figure 1). 


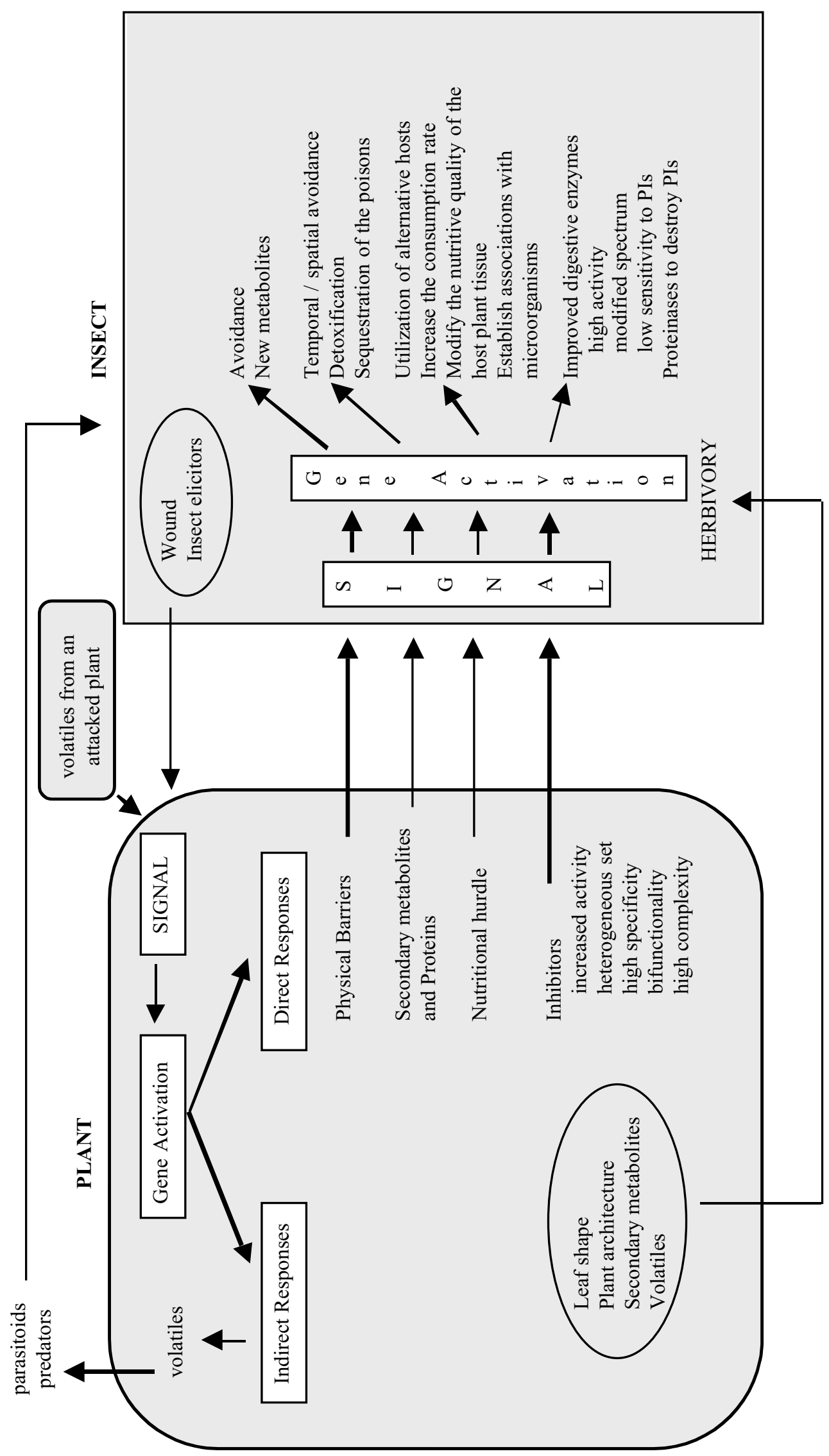

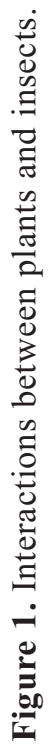


This is the base of the co-evolution theory proposed by Ehrlich and Raven in 1964. Even though this theory has been accepted by researchers, it is important to stress that certain plant defense compounds experience opposing selection pressure by different enemies and that major defensive barriers evolve in response to a diverse assemblage of herbivores and other biotic and abiotic factors (Stowe, 1998). Moreover, both organisms are under environmental pressures that have an important impact on this interaction system (Panda and Khush, 1995 and references herein). According to Stowe (1998), herbivores and other natural enemies challenge the plant resistance characters in multiple ways. On the other hand, plant populations counteract the facing mechanisms with a wide potential to respond to this selection pressure. Figure 1 summarizes the aspects that will be discussed in this review as well as the mechanisms involved in plant-insect interaction.

\section{Plant responses to insect attack}

Plants produce chemicals for defense purposes in two different ways; first, as constitutive substances to repel herbivores through direct toxicity or by reducing the digestibility of plant tissues and second, as inducible substances synthesized in response to tissue damage by herbivores. These strategies are able to prevent most of the herbivores although there are a reduced number of insects that are able to adapt to specific plant species.

Secondary metabolites perform useful functions for the plant acting either in an inducible or constitutive manner. Some compounds are plant growth regulators while others act as chemical signals in the ecosystem, antibiosis agents, transport and storage of carbon and nitrogen molecules which are directly involved in the plant primary metabolism (Panda and Khush, 1995). Secondary plant compounds are involved in plant defense against insect herbivores acting as insect repellents, feeding inhibitors and/or toxins. In this paper, we have classified these toxic compounds into chemical-derived substances (table 1) and protein-derived molecules (table $2)$. Glucosinolates are an example of secondary metabolites involved in plant/insect interactions. This class of molecules varies qualitatively in Arabidopsis plants, generating diverse combinations in response to changing herbivory or other selective pressures (Kliebenstein et al., 2001). The emission of volatile compounds is another important mechanism affecting the behavior of insects searching for food. Odors from plants are one of the primary cues that insects use to find the host plant. For example, cabbage seed weevil seems to be orientated by a complex mixture of host plant volatiles (Bartlet et al., 1993). The presence of chemical volatile compounds in plants indicates a double meaning. First, they can repel a wide range of potential herbivores due to the nature of toxic compounds released in the air. Second, they have the property of attracting a small number of specialized pest species and also of acting as an indirect plant defense mechanism by attracting other insects that prey on or parasitize the herbivores (Birkett et al., 2000). According to Kessler and Baldwin (2001), the volatile cocktail released by tobacco plants attracts predatory bugs to tobacco hornworm eggs and feeding larvae dramatically increasing the predation rates. Furthermore, these released volatiles decrease oviposition rates from adult moths since adults avoid plants on which predators are likely to be present, decreasing herbivore loads by $90 \%$. Plant volatiles may also act as signals between plants, where volatiles from a damaged tissue induce defense response in neighboring undamaged plants (Paré and Tumlinson, 1999). According to Paré and Tumlinson (1999), each plant produces a herbivorespecific blend of volatile components in response to a specific elicitor from a particular herbivore species feeding on the leaves. This strongly suggests the coevolution between plants, herbivores and their natural enemies.

Wounds created by herbivory can be opportunistically used as points of invasion by microorganisms and represent an increased risk of future pathogen attack (Paul et al., 2000). But the induced resistance allows maximum expression of the plant's potential to tolerate either herbivory or disease. This has been experimentally shown by the observation that insect feeding induces the production of phytoalexins, which have antimicrobial properties (Ananthakrishnan, 1999). In addition, intact cells surrounding areas of damaged tissue form physical barriers to restrict pathogen invasion by strengthening the cell wall, sealing the wound site or isolating the cells from their neighbors (de Bruxelles and Roberts, 2001).

According to Haruta et al. (2001), Populus tremuloides employs a wide range of defensive strategies against insect herbivores involving both protein and phytochemical-based components. The complex array of 
defense mechanisms has been adopted in most plantherbivore interactions. Although the production of several plant compounds can be very efficient to reduce insect damage, it is costly in most cases. During a herbivore attack, a plant might suffer two kinds of fitness consequences: tissue loss and large investments required for resistance. These costs are an important component for the evolution of resistance because an evolutionary equilibrium should be established at intermediate levels of herbivory reduction and fitness (Paul et al., 2000).
Therefore, plants might be able to circumvent allocation costs by evolving more efficient alternative biochemical pathways. Inducible defenses can be an alternative to reduce fitness cost since they minimize plant's expenditures by allowing it to invest in defense when necessary, and to avoid costly allocation to defense when herbivores are not present (Agrawal, 2000). Another alternative is used by some plants and is the suppression of the early and costly defense events at the moment of attack recognition (Baldwin, 2001).

Table 1. Chemical derived substances involved in host-plant resistance to insects.

Class/Subclass

alkanes, aldehydes, ketones, waxes

lignins, tannins

\section{Function}

protective layer

mechanical barrier, unpalatabil ity, postabsorptive inhibition

\begin{tabular}{ccc}
\hline $\begin{array}{c}\text { terpenoids (monoterpenoids, iridoids, } \\
\text { sesquiterpenoids, diterpenoids, triterpenoids) }\end{array}$ & $\begin{array}{c}\text { toxicants, antibiotic, feeding deterrents, } \\
\text { ovip osition deterrents }\end{array}$ & Nishida (2002) \\
\hline phenolics & toxicants, ovicidal, photosensitizing insects & Nishida (2002) \\
\hline $\begin{array}{c}\text { antifeedant, phytoalexins, inhibition of } \\
\text { mitochondrial oxidation }\end{array}$ & Ananthakrishnan (1999) \\
\hline isoflavonoids) & toxicants, antifeedant & Panda and Khush (1995) \\
\hline quinones & $\begin{array}{c}\text { toxicants, interfere in the nerve system, } \\
\text { digestive enzyme inhibitor, antifeedant, } \\
\text { glucosidase inhibitor }\end{array}$ & Panda and Khush (1995) \\
taloids & toxicant & Panda and Khush (1995) \\
\hline glucosinolates & repellent, to xicant, irritant, antibiotic & Kliebenstein et al. (2001) \\
\hline
\end{tabular}

Table 2. Protein-derived molecules involved in host-plant resistance to insects.

\begin{tabular}{|c|c|c|}
\hline Class/Subclass & Function & Reference \\
\hline lectins & $\begin{array}{l}\text { interfere in the absorption of nutrients, } \\
\text { in crease the absorption of toxic substances }\end{array}$ & Falco et al. (2001) \\
\hline chitinases & $\mathrm{d}$ amage the insect midgut & Falco et al. (2001) \\
\hline$\alpha$-amylase inhibitors & digestive enzyme inhibitor & Silva et al (2001) \\
\hline proteinase inhibitors & digestive enzyme inhibitors & Pompermayer et al (2001) \\
\hline indole-3-glycerol phosphate lyase (IGL) & formation of free indol & Frey et al.(2000) \\
\hline vegetative storage protein (VSP) & part of the systemic response & Stotz et al. (2000) \\
\hline glutathione S-transferase (GST) & detoxify or inactivate toxic compounds & Stotz et al. (2000) \\
\hline$\beta$-glucosidase 1 (BGL1) & unknown & Stotz et al. (2000) \\
\hline calcium binding elongation factor $(\mathrm{CaEF})$ & signaling pathway & Stotz et al. (2000) \\
\hline Hevein-like protein (HEL) & unknown & Reymond et al (2000) \\
\hline phospholipase A2 & generation of second messenger & Falco et al. (2001) \\
\hline MAPkinase & phosphorilation of transcription factors & Falco et al. (2001) \\
\hline polyphenol oxidade (PPO) & reduction of the nutritive value of protein & Falco et al. (2001) \\
\hline $\begin{array}{c}\text { 1-aminocyclopropane-1-carboxylic acid } \\
\text { o xidase (ACO) }\end{array}$ & ethy lene biosynthesis & Reymond et al (2000) \\
\hline allene oxide synthase (AOS) & JA biosynthesis & Reymond et al (2000) \\
\hline phenylalanine amonia-lyase (PAL) & phenylpropanoid pathway & Arim ura et al (2000) \\
\hline peroxidase & lignin synthesis, hipersensitive response & Arimura et al (2000) \\
\hline lipoxygenase (LOX) & JA biosynthes is & Arimura et al (2000) \\
\hline
\end{tabular}




\section{Herbivory/wounding signaling pathways}

The early events detected after wounding include ion fluxes across the plasma membrane, changes in cytoplasmic calcium concentration, generation of active oxygen species and changes in protein phosphorylation patterns (de Bruxelles and Roberts, 2001). These events lead to cell wall fortification at the wound site, alterations in metabolism and the generation of signals, which regulate defense gene expression. The signals that travel from damaged tissue throughout the plant include pectic fragments derived from the plant cell wall, jasmonic acid (JA), abscisic acid (ABA), ethylene, electrical potential, intermediates of the octadecanoid pathway (HPOTre, 12oxo-PDA), systemin (an 18-amino acid polypeptide isolated from leaves of tomato plants) and other plant polypeptide molecules (Ryan and Pearce, 2001).

Even though mechanical wounding is part of the damage caused by an insect attack, there are important differences between these two mechanisms of plant damage. For example, the wound-induced increase in JA levels is amplified by herbivore feeding and by the application of larval oral secretions or regurgitant to mechanical wounds, as well as the release of volatiles that attract parasitoids in an indirect defense mechanism (Halitschke et al., 2001). Different feeding mechanisms may account for some of the differences, but different elicitors may also be involved (Paré and Tumlinson, 1999). These substances are present in the oral secretion of herbivores. Two known products that trigger the synthesis and emission of volatile chemical signals have been reported so far: a $\beta$-glucosidase from Pieros brassicae caterpillars (Mattiacci et al., 1995) and a lowMr fatty acid derivative, N-(17-hydroxylinolenoyl)-L-Gln (volicitin) from beet army-worm caterpillars (Alborn et al., 1997).

After leaf damage and introduction of the elicitors, several not well-characterized events occur. In essence, systemin is released into the vascular system of damaged tissue activating the octadecanoid signaling cascade. Several reactions result in JA biosynthesis, up regulation of the synthesis of signal pathway genes (early genes) in the vascular bundles, and $\mathrm{H}_{2} \mathrm{O}_{2}$, which is a second messenger, that activates putative defense genes (late genes) such as the antifeedant proteinase inhibitor genes in mesophyll cells (de Bruxelles and Roberts, 2001; Orozco-Cárdenas et al., 2001). Even though JA is thought to be the predominant defense signal against chewing insects, ethylene seems to be an important defense modulator in different plant species, acting concomitantly or sequentially with JA in receiver leaves (Arimura et al., 2000; Stotz et al., 2000).

\section{Herbivore-induced plant gene expression}

The chemical and physical aspects of a plant are considerably altered following phytophagy. Induced responses to herbivory can reduce the preference and performance of a variety of herbivores, increase competitive ability against non-induced neighboring plants, increase tolerance to subsequent herbivory and, ultimately, increase plant fitness in natural environments (Agrawal, 2000). In addition, this represents an adaptive plasticity since the induced phenotype has greater fitness under strong herbivory while the non-induced phenotype shows the greatest fitness in an environment with low herbivory.

Several genes are selectively activated by volicitin, systemin or volatiles released from attacked plants. The genes encoding indole-3-glycerol phosphate lyase (IGL), that catalyses the formation of free indol, an important step in the formation of defense secondary metabolites (Frey et al., 2000), and allene synthase (AOS), that catalyzes the first step in JA biosynthesis (Reymond et al., 2000), are induced by herbivory. Additionally, Arimura et al. (2000) showed that volatiles released from lima bean leaves infested with Tetranychus urticae activated the expression of different classes of defense genes such as: lipoxygenase (LOX) via the octadecanoid pathway, phenylalanine ammonia-lyase (PAL) in the phenylpropanoid pathway, farnesyl pyrophosphate synthase in the isoprene biosynthetic pathway and pathogen-related (PR) genes in receiver leaves. On the other hand, the following gene products were induced in Arabidopsis rosette leaf tissue as a consequence of diamondback moth feeding: LOX2 (lypoxygenase), VSP (vegetative storage proteins), GST (glutathione Stransferase), BGL1 ( $\beta$-glucosidase 1 ) and CaEF (calcium binding elongation factor) (Stotz et al., 2000) (table 2). In a large survey on Arabidopsis leaves mechanically wounded or attacked by Pieris rapae using a c-DNA micro-array technique, Reymond et al. (2000) reported that a significant amount of genes was shown to be strongly up-regulated. Interestingly, another class of defense proteins, the Hevein-like protein (HEL), was only 
induced after insect feeding. On the other hand, many inducible genes were not induced by insect feeding. Studies on molecular interaction between Manduca sexta and Nicotiana attenuata demonstrated that the abundance of transcripts of the three photosynthesis $(c h l \mathrm{H}, l h b \mathrm{C} 1$ and $r b c \mathrm{~S})$, latex (pDH6.1) and cytoskeletal (pDH9.4) related genes, is strongly diminished by herbivory. This herbivore-induced suppression might benefit the plant allowing the redirection of the carbon flux toward defenses (Hermsmeier et al., 2001). In sugarcane, a computer-assisted analysis of 26 different cDNA libraries from the Sugarcane EST (Expressed Sequence Tag) Project (SUCEST) identified several orthologues of genes involved in plant response to insect damage either as signal receptors, signal pathway and proteolysis associated or defensive related proteins (Falco et al., 2001).

\section{Storage proteins and plant defense}

The synthesis and accumulation of a variety of storage proteins have been shown to be closely related to plant defense since several of these proteins present entomotoxic properties such as $\alpha$-amylase and proteinase inhibitors, lectins and globulins. These proteins are usually present in seeds and vegetative organs of leguminous plants (Negreiros et al., 1991; Sales et al., 2000; Franco et al., 2002).

Proteinase inhibitor (PI) levels in plant leaves are normally low but they can be actively induced to high levels when plants are attacked by insects, suffer mechanical damage or are exposed to exogenous phytohormones (Rakwal et al., 2001). In addition to a local inducible synthesis of PIs, it was demonstrated that specific signals from the damaged tissue are transported via phloem and stimulate the synthesis of PIs throughout the plant (Jongsma and Bolter, 1997). Plant proteinase inhibitors function as specific substrates for the digestive proteinases, forming a stable complex in which proteolysis is limited and extremely slow (Tiffin and Gaut, 2001). Ultimately, proteinase inhibitors act by causing an amino acid deficiency influencing the insect growth, development and eventually causing their death either by inhibition of gut proteinases or due to a massive overproduction of the digestive enzymes, reducing the availability of essential amino acids for the production of other proteins (Jongsma and Bolter, 1997;
Pompermayer et al., 2001). Slowing herbivore growth, these inhibitors prolong the time that predators could be attracted to plants by the volatile release. Direct defenses that extend the time during which larvae remain in these instars would probably increase the effectiveness of the indirect defense (Baldwin 2001).

Transgenic tomato plants overexpressing the prosystemin transgene have been shown to accumulate a soluble cystatin constitutively. In leaves of wild-type tomato plants, cystatin mRNA accumulated systemically in response to wounding, treatment with metyl jasmonate and when supplied with systemin (Siqueira-Junior et al., 2002). According to the authors, midgut homogenate of third-instar larvae of Callosobruchus maculatus and Zabrotes subfasciatus had their proteolytic activity content significantly inhibited by tomato cystatin.

Moura and Ryan (2001) demonstrated that the induction of proteinase inhibitors in pepper in response to herbivore is regulated through the octadecanoidsignaling pathway. However, there are some differences in the process in pepper when compared to the process previously described for tomato (Pearce et al., 1991). According to the authors, this could indicate that PIencoding genes in different species might have evolved to defend them against specific pests and pathogens belonging to their unique ecological niches. Besides a rapid response to insect attack, induced PIs can play a preventive role in plant defense. For example, attacked Populus tremuloides leaves accumulate trypsin inhibitor within 2 days in turn to reduce subsequent damage (Haruta et al., 2001).

During evolution, plants and insects developed ecological, physiological and biochemical mechanisms to weaken the effect of insect proteinases and plant proteinase inhibitors, respectively. Plants evolved extraordinary characteristics against insect proteinases by increasing the inhibitor activity in their tissues (Rakwal et al., 2001), by developing a heterogeneous set of inhibitors possessing activities to various enzymes (Christeller et al., 1998), by producing bifunctional inhibitors which are active to amylases and proteinases (Roy and Gupta, 2000), by increasing the complexity of inhibitors with different biochemical properties through the production of isoinhibitors (Tiffin and Gaut, 2001), by forming highly specific inhibitors of insect enzymes (Falco et al., 2001) and by the synthesis of inhibitors 
resistant to proteolysis and active under diverse gut $\mathrm{pH}$ (Christeller et al., 1998). In their turn, insects have found diverse ways of avoiding negative effects caused by the proteinase inhibitors present on their host plants. These include the increase in the activity of their digestive enzymes or by the synthesis of less sensitive enzymes (Paulillo et al., 2000), the modification of the spectrum or the relative activities of various digestive hydrolases (Patankar et al., 2001), the breakdown of the inhibitors in the gut via proteinases (Girard et al., 1998) and the decrease of the sensitivity of their enzymes to the inhibitors (Brito et al., 2001) by a rapid response that up-regulates the gene expression of PI-insensitive proteinases in order to compensate for the inhibited ones.

Lectins are carbohydrate-binding proteins usually found in legume plants, mainly in the storage organs and protective structures (Ramos et al., 2001). The common bean (Phaseolus vulgaris) presents three classes of these insecticidal proteins, phytohemagglutinins, arcelins and $\alpha$-amylase inhibitors which comprise the bean-lectin gene family (Moreno and Chrispeels, 1989; Chrispeels and Raikhel, 1991). The entomotoxic effect of plant lectins has been evaluated in different insect orders. The jack bean (Canavalia ensiforms) lectin was shown to interfere in insect development in both the Lepidoptera (Lacanobia oleracea) and Hemiptera (Myzus persicae and Rhodnius prolixus) orders (Gatehouse at al., 1999; Ferreira-da-Silva et al., 2000).

Vicilins, which belong to the globulin family, are another class of storage proteins found in leguminous seeds (Oliveira et al., 1999). They bind strongly to several chitin-containing structures found in insect midguts and cell walls or plasma membranes of filamentous fungi and yeast, interfering negatively in the growth and development of the invader organism (Sales et al., 2000). These proteins are responsible for the resistance of cowpea (Vigna unguiculata) seeds to Callosobruchus maculatus (Macedo et al., 1993). Part of this resistance could be accounted for by the low rates of vicilins hydrolysis by the C. maculatus midgut enzymes (Sales et al., 1992).

\section{Insect response mechanisms}

Insects have developed different patterns of host plant associations coupled with different life histories and feeding strategies necessary for the exploitation of their hosts (Panda and Khush, 1995). According to Price (1997), closely related plants support closely related insects. This is due to the evolutionary process where slight but permanent changes in insect enzyme assortment permitted the exploitation of closely related plants. When an insect species develops a mechanism that enables it to use a toxic plant for food, several advantages are observed. This plant can be easily recognized by its secondary compounds and constitutes a source of food that can be used by very few other herbivores, minimizing the competition. This has a protective implication since the antibiotic properties of many toxic chemicals may protect the herbivore against pathogens and feeding on this food may also impart a toxic or unpalatable characteristic to the herbivore, reducing predation.

\section{Insect adaptation to plant defense barriers}

Insect herbivores present complementary adaptations as a response to each defensive adaptation in host plants (figure 1). It is evident that insects are successful in terms of number of species and population size (Price, 1997). Plant chemical composition is variable and represents a challenge for insect feeding. However, insects possess a powerful assemblage of enzymes that constitute their defense against chemical toxicants. One of the strategies to overcome this problem is the detoxification of defense chemicals by oxidation, reduction, hydrolysis or conjugation of molecules (Scott and Wen, 2001). An interesting case of interaction between host plants and herbivore insects was shown by Berenbaum and Zangerl (1998). In this study, variations in plant production of furanocoumarins were accompanied by variation in the ability of the insect to metabolize these compounds. According to the authors, these high levels of matching between phenotypes suggest that the genes conferring ability to exploit hosts are tightly linked. An example of genes involved in plant-insect interactions and insect physiology is the cytochrome P450-dependent monooxygenase. Studying Papilio polyxenes behavior, Scott and Wen (2001) demonstrated that this insect appears to have adapted to feeding on toxin-containing host plants through a diversification of the P450s involved in detoxification and through its furanocoumarinresponsive regulatory cascades.

Another manner for insects to avoid plant poisons is by sequestering and deploying the poisons for their own 
pheromone system and defense (Nishida, 2002), or simply feeding on parts of the plant that lack these compounds (Zangerl, 1990). Lepidoptera sequesters plant secondary metabolites such some terpenes, phenols and many nitrogen-containing compounds and uses them as toxic or unpalatable to predators (Nishida, 2002). An example of this adaptation is illustrated by the tobacco hornworm. This insect accumulates the nicotine synthesized by tobacco plants in its own body which is toxic to most insects and uses it as a deterrent to parasitoids (de Bruxelles and Roberts, 2001). On the other hand, the presence of caffeine, the major alkaloid in coffee, is not effective against the Perileucoptera coffeella larvae. This suggests that insect adaptation to this potentially toxic compound was probably due to a tolerance mechanism (Guerreiro and Mazzafera, 2000). Recently, an interesting mechanism of avoiding toxic substances was observed by Musser et al. (2002). In their research, glucose oxidase, one of the principal components of Helicoverpa zea saliva, was detected as responsible for suppressing induced resistance in tobacco plants. They infer that this enzyme may prevent the induction of nicotine by inhibition of the signaling pathway.

Natural selection acts in a way to synchronize insect and plant life cycles. Then, insects can feed, grow and reproduce when plants are actively growing and represent a suitable source of nutrients and shelter. If dietary quality changes, insects have the ability to overcome this situation by using different parts of the plant, increasing the consumption rate (Slansky and Weeler, 1989), modifying the nutritive quality of host plant tissues or establishing associations with symbiont microorganisms. The way they adjust their food quality intake and assimilation rate assures the maintenance of their growth and development.

Protein inhibitors are important plant chemical barriers that should be circumvented by herbivore insects. Patankar et al. (2001) showed that Helicoverpa armigera larvae is able to overcome the effect of various host plant PIs by altering its midgut composition after PIs ingestion, that was also observed for Agrotis ipsilon and Helicoverpa zea (Mazumdar-Leighton and Broadway, 2001a,b). Newly synthesized trypsins from Heliothis virescens form oligomers that are less affected by PIs since they bind tighter to the substrate and putatively decrease affinity for PIs (Brito et al., 2001). Recently, Mazumdar-Leighton and Broadway (2001a) showed that lepidopteran insects have constitutive trypsins and trypsins induced after ingestion of PIs that are insensitive to the inhibitors. Similar results were also reported for chymotrypsins (Mazumdar-Leighton and Broadway, 2001b) and $\alpha$ amylase (Silva et al., 2001). In addition, production of PI-digesting proteinases allows the insect to overcome the plant defense and also to use the digested inhibitor as a source of amino acids (Girard et al., 1998).

\section{Generalists x Specialists}

According to Bernays and Chapman (1994), plantfeeding insects can be classified as generalist or specialist herbivores. Generalist insect herbivores rear on a wide variety of plant species and their adaptive mechanisms are more complex since polyphagous insects tend to respond to a large array of different plant chemicals and proteins. On the other hand, specialist insect herbivores hosting only on a few related plant species might be expected to have a more efficient form of adaptation, either involving the production of large quantities of an enzyme to detoxify their food, or evolve storage mechanisms (Jongsma and Bolter, 1997; Price, 1997; Patankar et al., 2001). Eruptive insect herbivores commonly adopt a generalist feeding strategy. Even though they are able to grow and develop on a variety of host plant species, their performance is highly influenced. Some of the observed effects are reduced growth and larval survival (Lazarevic et al., 1998), abnormal development at the pupal stage, delay in adult emergence (Hunter and McNeil, 1997), decrease of adult weight (Tikkanen et al., 2000) and finally, a reduced number of generations (Hunter and McNeil, 1997; Tikkanen et al., 2000). The majority of insect herbivores are relative specialists, using a restricted number of hosts with similar phytochemicals and taking advantage to colonize an open niche (Bernays, 2001). During the course of evolution, specialist herbivores adapted to plant chemical defenses developing mechanisms that use these chemicals as attractants. These insects frequently detoxify or sequester plant defense compounds and, sometimes, they result in protection against parasitoids and predators being used as toxic or unpalatable at defense. Sequestering specialists have developed the ability to incorporate these compounds with relative impunity, ingesting, transporting and depositing the substances to be sequestered in particular sites of the larvae, adult body and even in the eggs (Nishida, 2002). Further, these compounds are of great 
importance since they provide insects with signals for identification of the host, turning the process of host finding at feeding and oviposition rapid and efficient. On the other hand, secondary metabolites of a non-host plant have the potential to deter specialists that show an equal sensitivity to these phytochemicals. The ability to choose superior hosts is shown to be greater in specialists than in relative generalists in the presence of a choice of mixed-quality hosts (Bernays, 2001).

The co-evolution of plants and insects is very intriguing. Plants have developed efficient mechanisms to protect them against herbivory while insects have found diverse ways of avoiding negative effects of their host plants defense mechanisms. Even though many workers have attempted to study plant-insect interaction, our knowledge is still limited. The better understanding of this process will allow us to achieve more effective methods for the biological control of insect pests with natural products by the development of new plant varieties with enhanced chemical defenses.

Acknowledgments: This work was supported by Fundação de Amparo a Pesquisa do Estado de São Paulo (FAPESP), grant 97/04934-3, and Pronex. M.O.M. is supported by a graduate fellowship from FAPESP. M.C.S.F. is a research fellow of CNPq (Brasília, Brazil).

\section{REFERENCES}

Agrawal AA (2000) Benefits and costs of induced plant defense for Lepidium virginicum (Brassicaceae). Ecology 81:1804-1813.

Alborn HT, Turlings TC, Jones TH, Stenhagen G, Loughrin JH, Tumlinson JH (1997) An elicitor of plant volatiles from beet armyworm oral secretion. Science 276:945-949.

Ananthakrishnan TN (1999) Induced responses, signal diversity and plant defense: Implications in insect phytophagy. Curr. Sci. 76:285-290.

Arimura G-I, Ozawa R, Shimoda T, Nishioka T, Boland W, Takabayashi J (2000) Herbivory-induced volatiles elicit defense genes in lima bean leaves. Nature 406:512-515.

Baldwin IT (2001) An ecologically motivated analysis of plant-herbivore interactions in native tobacco. Plant Physiol. 127:1449-1458.

Bartlet E, Blight MM, Hick AJ, Williams IH (1993) The responses of the cabbage seed weevil (Ceutorhynchus assimilis) to the odour of oilseed rape (Brassica napus) and to some volatile isothiocyanates. Entomol. Exp. Appl. 68:295-302.

Berenbaum MR, Zangerl AR (1998) Chemical phenotype matching between a plant and its insect herbivore. Proc. Natl. Acad. Sci. USA 95:13743-13748.

Bernays EA (2001) Neural limitations in phytophagous insects: Implications for diet breadth and evolution of host affiliation. Annu. Rev. Entomol. 46:703-727.

Bernays EA, Chapman RF (1994) Host plant selection by phytophagous insects. Chapman and Hall, London.

Birkett MA, Campbell CAM, Chamberlain K, Guerrieri E, Hick AJ, Martin JL, Matthes M, Napier JA, Pettersson J, Pickett JA, Poppy GM, Pow EM, Pye BJ, Smart LE, Wadhams GH, Wadhams LJ, Woodcock CM (2000) New roles for cis-jasmone as an insect semiochemical and in plant defense. Proc. Natl Acad. Sci. USA 97:9329-9334.

Brito LO, Lopes AR, Parra JRP, Terra WR, Silva-Filho, MC (2001) Adaptation of tobacco budworm Heliothis virescens to proteinase inhibitors may be mediated by the synthesis of new proteinases. Comp. Biochem. Physiol. 128B:365-375.

Chrispeels MJ, Raikhel NV (1991) Lectins, lectin genes, and their role in plant defense. Plant Cell 3:1-9.

Christeller JT, Farley PC, Ramsay RJ, Sullivan PA, Laing WA (1998) Purification, characterization and clonning of an aspartic proteinase inhibitor from squash phloem exudate. Eur. J. Biochem. 254:160-167.

de Bruxelles GL, Roberts MR (2001) Signals regulating multiple responses to wounding and herbivores. Crit. Rev. Plant Sci. 20:487-521.

Ehrlich PR, Raven PH (1964) Butterflies and plants: A study in coevolution. Evolution 18:586-608.

Falco MC, Marbach PAS, Pompermayer P, Lopes FCC, Silva-Filho MC (2001) Mechanisms of sugarcane response to herbivory. Genet. Mol. Biol. 24:113-122.

Ferreira-da-Silva CT, Gombarovits ME, Masuda H, Oliveira CM, Carlini CR (2000) Proteolytic activation of canatoxin, a plant toxic protein, by insect cathepsin-like enzymes. Arch. Insect Biochem. Physiol. 44:162-171.

Fordyce JA, Agrawal AA (2001) The role of plant trichomes and caterpillar group size on growth and defense of the pipevine swallowtail Battus philenor. J. Animal Ecol. 70:997-1005.

Franco OL, Rigden DJ, Melo FR, Grossi-de-Sá MF (2002) Plant alpha-amylase inhibitors and their interaction with insect alpha-amylases-structure, function and potential for crop protection. Eur. J. Biochem. 269:397-412. 
Frey M, Stettner C, Paré PW, Schmelz EA, Tumlinson JH, Gierl A (2000) An herbivore elicitor activates the gene for indole emission in maize. Proc. Natl. Acad. Sci. USA 97:14801-14806.

Gatehouse AMR, Davison GM, Stewart JN, Galehouse LN, Kumar A, Geoghegan IE, Birch ANE, Gatehouse JA (1999) Concanavalin A inhibits development of tomato moth (Lacanobia oleracea) and peach-potato aphid (Myzus persicae) when expressed in transgenic potato plants. Mol. Breed. 5:153-165.

Girard C, Le Métayer M, Bonadé-Bottino M, PhamDelègue MH, Jouanin L (1998) High level of resistance to proteinase inhibitors may be conferred by proteolytic cleavage in bettle larvae. Insect Biochem. Mol. Biol. 28:229-237.

Guerreiro Filho O, Mazzafera P (2000) Caffeine does not protect coffee against the leaf miner Perileucoptera coffeella. J. Chem. Ecol. 26:1447-1464.

Halitschke R, Schittko U, Pohnert G, Boland W, Baldwin IT (2001) Molecular interactions between the specialist herbivore Manduca sexta (Lepidopetra, Sphingidae) and its natural host Nicotiana attenuata. III. Fatty Acid-Amino Acid conjugates in herbivore oral secretions are necessary and sufficient for herbivore-specific plant responses. Plant Physiol. 125:711-717.

Haruta M, Major IT, Christopher ME, Patton JJ, Constabel CP (2001) A Kunitz trypsin inhibitor gene family from trembling aspen (Populus tremuloides Michx.): cloning, functional expression, and induction by wounding and herbivory. Plant Mol. Biol. 46:347-359.

Hermsmeier D, Schittko U, Baldwin IT (2001) Molecular interactions between the specialist herbivore Manduca sexta (Lepidopetra, Sphingidae) and its natural host Nicotiana attenuata. I. Large-scale changes in the accumulation of growth- and defense-related plant mRNAs. Plant Physiol. 125:683-700.

Hunter MD, McNeil JN (1997) Host-plant quality influences diapause and voltinism in a polyphagous insect herbivore. Ecology 78:977-986.

Jongsma MA, Bolter C (1997) The adaptation of insects to plant protease inhibitors. J. Insect Physiol. 43:885-895.

Kessler A, Baldwin IT (2001) Defensive function of herbivore-induced plant volatile emissions in nature. Science 291:2141-2144.

Kliebenstein DJ, Kroymann J, Brown P, Figuth A, Pedersen D, Gershenzon J, Mitchell-Olds T (2001) Genetic control of natural variation in Arabidopsis glucosinolate accumulation. Plant Physiol. 126:811-825.
Lazarevic J, Peric-Mataruga V, Ivanovic J, Andjelkovic M (1998) Host plant effects on the genetic variation and correlations in the individual performance of the gypsy moth. Funct. Ecol. 12:141-148.

Macedo MLR, Andrade LBS, Moraes RA, Xavier-Filho J (1993) Vicilin variants and the resistance of cowpea (Vigna unguiculata) seeds to the cowpea weevil (Callosobruchus maculatus). Comp. Biochem. Physiol. 105C:89-94.

Mattiacci L, Dicke M, Posthumus MA (1995) $\beta$ glucosidase: an elicitor of herbivore-induced plant odor that attracts host-searching parasitic wasps. Proc. Natl. Acad. Sci. USA 92:2036-2040.

Mazumdar-Leighton S, Broadway RM (2001a) Transcriptional induction of diverse midgut trypsins in larval Agrotis ipsilon and Helicoverpa zea feeding on the soybean trypsin inhibitor. Insect Biochem. Mol. Biol. 31:645-657.

Mazumdar-Leighton S, Broadway RM (2001b) Identification of six chymotrypsin cDNAs from larval midguts of Helicoverpa zea and Agrotis ipsilon feeding on the soybean (Kunitz) trypsin inhibitor. Insect Biochem. Mol. Biol. 31:633-644.

Moreno J, Chrispeels MJ (1989) A lectin gene encodes the alpha-amylase inhibitor of the common bean. Proc. Natl. Acad. Sci. USA 86:7885-7889.

Moura DS, Ryan, CA (2001) Wound-inducible proteinase inhibitors in peper. Differential regulation upon wounding, systemin, and methyl jasmonate. Plant Physiol. 126:289-298.

Musser RO, Hum-Musser SM, Eichenseer H, Peiffer M, Ervin G, Murphy JB, Felton GW (2002) Caterpillar saliva beats plant defences. Nature 416:599-600.

Negreiros AN, Carvalho MM, Xavier-Filho J, BlancoLabra A, Shewry PR, Richardson M (1991) The complete amino acid sequence of the major Kunitz trypsin inhibitor from the seeds of Prosopsis juliflora. Phytochemistry 30:2829-2833.

Nishida R (2002) Sequestration of defensive substances from plants by lepidoptera. Annu. Rev. Entomol. 47:57-92.

Oliveira AEA, Sales MP, Machado OLT, Fernandes KVS, Xavier-Filho J (1999) The toxicity of the jack bean (Canavalia ensiformis) cotyledonary and testa proteins to the cowpea weevil (Callosobruchus maculatus). Entomol. Exp. Appl. 92:249-255.

Orozco-Cárdenas ML, Narváez-Vásquez J, Ryan CA (2001) Hydrogen peroxide acts as a second messenger for the induction of defense genes in tomato plants in 
response to wounding, systemin, and methyl jasmonate. The Plant Cell 13:179-191.

Panda N, Khush GS (1995) Host plant resistance to insects. CAB International, Wallingford.

Paré PW, Tumlinson JH (1999) Plant volatiles as a defense against insect herbivores. Plant Physiol. 121:325-331.

Patankar AG, Giri AP, Harsulkar AM, Sainani MN, Deshpande VV, Ranjekar PK, Gupta VS (2001) Complexity in specificities and expression of Helicoverpa armigera gut proteinases explains polyphagous nature of the insect pest. Insect Biochem. Mol. Biol. 31:453-464.

Paul ND, Hatcher PE, Taylor JE (2000) Coping with multiple enemies: an integration of molecular and ecological perspectives. Trends Plant Sci. 5:220-225.

Paulillo LCMS, Lopes AR, Cristofoletti PT, Parra JRP, Terra WR, Silva-Filho MC (2000) Changes in midgut endopeptidase activity of Spodoptera frugiperda (Lepidoptera: Noctuidae) are responsible for adaptation to soybean proteinase inhibitors. J. Econ. Entomol. 93:892-896.

Pearce G, Strydom D, Johnson S, Ryan CA (1991) A polypeptide from tomato leaves induces woundinducible proteinase inhibitor proteins. Science 253:895-898

Pompermayer P, Lopes AR, Terra WR, Parra JRP, Falco MC, Silva-Filho MC (2001) Effects of soybean proteinase inhibitor on development, survival and reproductive potential of the sugarcane borer, Diatraea saccharalis. Entomol. Exp. Appl. 99:79-85.

Price PW (1997) Insect Ecology. $3^{\text {rd }}$ edn. John Wiley \& Sons, Inc, New York.

Ramos MV, Sampaio AH, Cavada BS, Calvete JJ, Grangeiro TB, Debray H (2001) Characterization of the sugar-binding specificity of the toxic lectins isolated from Abrus pulchellus seeds. Glycoconj. J. 18:391-400.

Rakwal R, Agrawal GK, Jwa NS (2001) Characterization of a rice (Oryza sativa L.) Bowman-Birk proteinase inhibitor:tightly light regulated induction in response to cut, jasmonic acid, ethylene and protein phosphatase 2A inhibitors. Gene 263:189-198.

Reymond P, Weber H, Damond M, Farmer EE (2000) Differential gene expression in response to mechanical wounding and insect feeding in Arabidopsis. The Plant Cell 12:707-719.

Roy I, Gupta MN (2000) Purification of a "doubleheaded" inhibitor of alpha-amylase/proteinase K from wheat germ by expanded bed chromatography. Bioseparation 9:239-245.
Ryan CA, Pearce G (2001) Polypeptide hormones. Plant Physiol. 125:65-68.

Sales MP, Macedo MLR, Xavier-Filho J (1992) Digestibility of cowpea (Vigna unguiculata) vicilins by pepsin, papain and bruchid midgut proteinases. Comp. Biochem. Physiol. 103B:945-950.

Sales MP, Gerhardt IR, Grossi-de-Sá MF, Xavier-Filho J (2000) Do legume storage proteins play a role in defending seeds against bruchids? Plant Physiol. 124:515-522.

Scott JG, Wen ZM (2001) Cytochromes P450 of insects: the tip of the iceberg. Pest Manag. Sci. 57:958-967.

Silva CP, Terra WR, Grossi de Sá MF, Samuels RI, Isejima EM, Bifano TD, Almeida JS (2001) Induction of digestive $\alpha$-amylases in larvae of Zabrotes subfasciatus (Coleoptera: Bruchidae) in response to ingestion of common bean $\alpha$-amylase inhibitor 1 . J. Insect Physiol. 47:1283-1290.

Siqueira-Junior CL, Fernandes KVS, Machado OLT, da Cunha M, Gomes VM, Moura D, Jacinto T (2002) $87 \mathrm{kDa}$ tomato cystatin exhibits properties of a defense protein and forms protein crystals in prosystemin overexpressing transgenic plants. Plant Physiol. Biochem. 40:247-254.

Slansky F, Wheeler GS (1989) Compensatory increases in food consumption and utilization efficiencies by velvetbean caterpillars mitigate impact of diluted diets on growth. Entomol. Exp. Appl. 51:175-187.

Stotz, HU, Pittendrigh BR, Kroymann J, Weniger K, Fritsche J, Bauke A, Mitchell-Olds T (2000) Induced plant defense responses against chewing insects. Ethylene signaling reduces resistance of Arabidopsis against egyptian cotton worm but not diamondback moth. Plant Physiol. 124:1007-1017.

Stowe KA (1998) Experimental evolution of resistance in Brassica rapa: Correlated response of tolerance in lines selected for glucosinolate content. Evolution 52:703-712.

Tiffin P, Gaut BS (2001) Molecular evolution of the wound-induced serine protease inhibitor wip1 in Zea and related genera. Mol. Biol. Evol. 18:2092-2101.

Tikkanen O-P, Niemelä P, Keränen J (2000) Growth and development of a generalist insect herbivore, Operophtera brumata, on original and alternative host plants. Oecologia 122:529-536.

Zangerl AR (1990) Furanocoumarin induction in wild parsnip: evidence for an induced defense against herbivores. Ecology 71:1926-1932. 